\title{
SYNTHESIS OF DUMORTIERITE IN THE SYSTEM $\mathrm{Al}_{2} \mathrm{O}_{3}-\mathrm{SiO}_{2}-\mathrm{B}_{2} \mathrm{O}_{3}-\mathrm{H}_{2} \mathrm{O}$
}

\author{
AKIRA ONO \\ National Institute for Researches in Inorganic Materials 1-1 Namiki, \\ Sakura-mura, Ibaraki 305 Japan
}

\begin{abstract}
Synthesis of dumortierite indicates that stoichiometric dumortierite is unstable. Compositional variation of synthetic dumortierite is almost absent regardless of wide range of synthetic temperature and difference in coexisting minerals. Substitutions of $\mathrm{Al}-\mathrm{O} \rightleftharpoons$ $\mathrm{Al}-\mathrm{OH}$ and $\mathrm{AlO}_{6} \rightleftharpoons \mathrm{BO}_{6}$ in dumortierite are revealed by chemical analyses and infrared spectroscopic study.
\end{abstract}

\section{INTRODUCTION}

Crystallochemical formula of dumortierite is considered as $\mathrm{Al}_{7} \mathrm{O}_{3}\left(\mathrm{BO}_{3}\right)\left(\mathrm{SiO}_{4}\right)_{3}$. However, chemical analyses of natural dumortierite show small amounts of $\mathrm{H}_{2} \mathrm{O}$ (Claringbull and Hey, 1958). Sum of weight percentages of $\mathrm{Al}_{2} \mathrm{O}_{3}$ and $\mathrm{SiO}_{2}$ of any dumortierite from the Ryoke pelitic gneisses are considerably small as compared with ideal composition, $\mathrm{Al}_{7} \mathrm{O}_{3}\left(\mathrm{BO}_{3}\right)\left(\mathrm{SiO}_{4}\right)_{3}($ Ono, 1977). Synthesis of dumortierite was carried out to elucidate these problems.

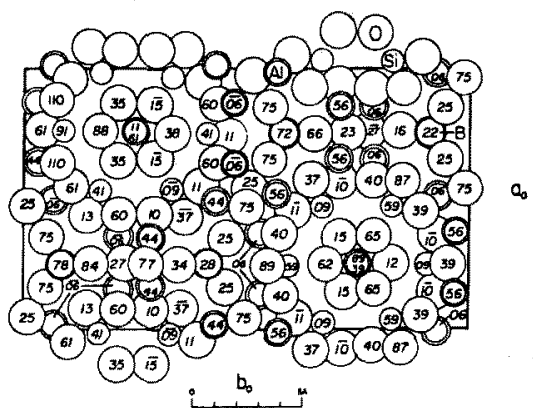

Fig. 1 Structure of dumorierite.

\section{CRystal Structure}

Dumoriterite is a nesosubsilicate consisting of isolated $\mathrm{SiO}_{4}$ tetrahedra, with $\mathrm{BO}_{3}$ triangles as additional anions. The $\mathrm{SiO}_{4}$ tetrahedra are held together by $\mathrm{Al}$ ions in octahedral site (Fig. 1). Viewing down the [001] direction, the crystal can be considered as consisting of channels with $\mathrm{AlO}_{3}$ octahedra and $\mathrm{BO}_{3}$ triangles (Wyckoff, 1968).

Table 1. Chemical compositions of the starting materials

\begin{tabular}{l|rr} 
& \multicolumn{1}{|c}{$\mathrm{a}$} & $\mathrm{d}$ \\
\hline $\mathrm{SiO}_{2}$ & 30.10 & 25.53 \\
$\mathrm{Al}_{2} \mathrm{O}_{3}$ & 59.59 & 54.24 \\
$\mathrm{~B}_{2} \mathrm{O}_{3}$ & 5.81 & 11.39 \\
$\mathrm{H}_{2} \mathrm{O}$ & 4.50 & 8.84 \\
\hline Total & 100.00 & 100.00
\end{tabular}

\section{METHOD OF SYNTHESIS}

Starting materials were prepared by mixing mechanically $\mathrm{SiO}_{2}, \mathrm{Al}_{2} \mathrm{O}_{3}$ and $\mathrm{H}_{3} \mathrm{BO}_{3}$. 
$\mathrm{SiO}_{2}$ and $\mathrm{Al}_{2} \mathrm{O}_{3}$ were prepared from $\mathrm{H}_{2} \mathrm{SiO}_{3}$ and $\mathrm{Al}(\mathrm{OH})_{3}$ at $1500^{\circ} \mathrm{C}$. Table 1 shows the chemical compositions of the starting materials. Chemical composition "a" in Table 1 corresponds to the stoichiometric formula $\mathrm{Al}_{7} \mathrm{O}_{3}\left(\mathrm{BO}_{3}\right)\left(\mathrm{SiO}_{4}\right)_{3}$. " $\mathrm{d}$ " in Table $\mathrm{l}$ is $\mathrm{B}_{2} \mathrm{O}_{3}$-excess as compared with synthetic dumortierite. Mixture of " $\mathrm{d}$ " and $\mathrm{SiO}_{2}$ are also used as a starting material in a few experimental runs.

The synthesis of dumortierite was carried out by Boyd-England type single stage piston sylinder apparatus of $12.75 \mathrm{~mm}$ in diameter designed by $\mathrm{O}$. Fukunaga. $\mathrm{NaCl}$ with $5 \% \quad \mathrm{MoS}_{2}$, pyrex glass and Alsimag ceramics were used as the pressure medium. Pressure values are uncorrected data of the nominal pressure. Chromelalumel thermocouples were used in all runs for the temperature measurements. The duration of experimental runs was 1 to 95 hours. Starting materials were sealed in platinum tube with no water added. The products of the runs were identified by X-ray diffraction patterns, optical properties and chemical compositions analyzed by an electron probe microanalyzer.

\section{Analytical Method}

Synthetic dumortierite were analyzed by an electron probe microanalyzer. Analyti- cal procedures are as follows: 1) determination of apparent concentrations of $\mathrm{SiO}_{2}$ and $\mathrm{Al}_{2} \mathrm{O}_{3}$. 2) $\mathrm{ZAF}$ correction procedure was carried out. Dumortierite was treated as the ternary system $\mathrm{Al}_{2} \mathrm{O}_{3}-\mathrm{SiO}_{2}-\mathrm{B}_{2} \mathrm{O}_{3}$. Apparent boron content was assumed so as to attain 100 per centage in sum of oxide components after the ZAF correction. 3) Chemical compositions obtained by this procedure are different from the ideal composition of $\mathrm{Al}_{7} \mathrm{O}_{3}\left(\mathrm{BO}_{3}\right)\left(\mathrm{SiO}_{4}\right)_{3}$. Boron atom per formula unit on the basis of 18 oxygen always exceeds 1.5. Occupany of $\mathrm{Al}$ atom in the tetrahedral Si positions is significant. Thus, charge neutrality is only achieved by exceeding the seven positions of $\mathrm{Al}$ octahedral sites available in the crystal structure. 4) We propose, therefore, the following chemical formula for dumortierite crystal.

$\mathrm{Al}_{6}\left(\mathrm{~B}_{\mathrm{x}}, \mathrm{Al}_{1-\mathrm{x}}\right) \mathrm{O}_{3}\left(\mathrm{BO}_{3}\right)\left[\left(\mathrm{Si}_{3-y}, \mathrm{Al}_{y}\right) \mathrm{O}_{12-y}\right](\mathrm{OH})_{y}$ Chemical compositions of dumortierite were recalculated so as to support the above chemical formula. In this recalculation, the $\mathrm{Al}_{2} \mathrm{O}_{3}$ and $\mathrm{SiO}_{2}$ contents were not changed, and the $\mathrm{B}_{2} \mathrm{O}_{3}$ contents were subtracted and the $\mathrm{H}_{2} \mathrm{O}$ contents were added. Because the amount of $\mathrm{H}_{2} \mathrm{O}$ content is very small, this procedure may be correct. New chemical formula is based on supposing substitution of oxygen $(\mathrm{O}(1)$ and $\mathrm{O}(2)$ after Wyckoff (1968)) by $\mathrm{OH}$.

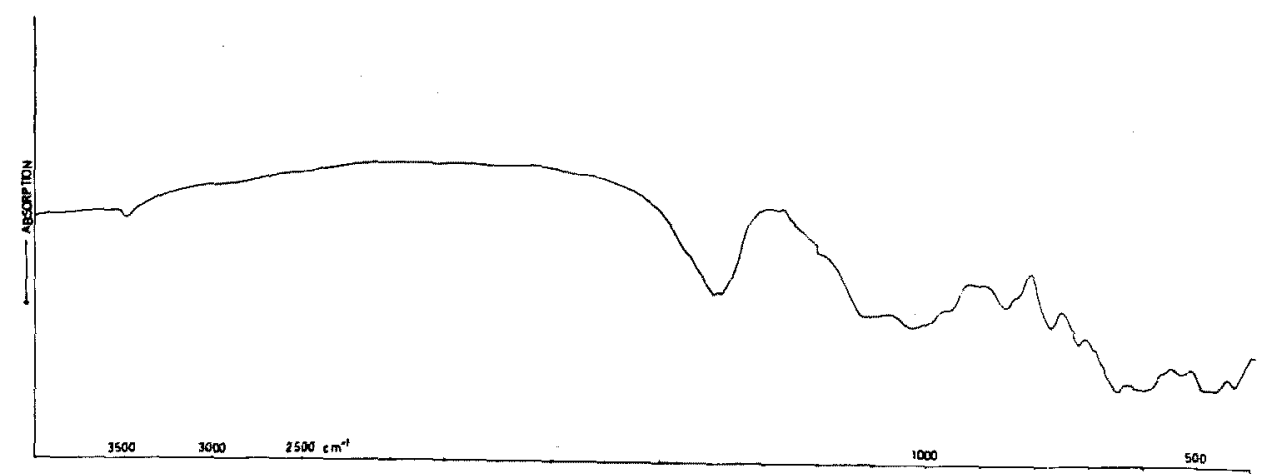

Fig. 2 Infrared spectrum of dumortierite. 


\section{INFRARED SPECTROSCOPY}

Synthetic dumortierite were purified by dissolving out impurities with $\mathrm{HF}-\mathrm{HCl}$ acid. $\mathrm{KBr}$ pellets containing small amount of acid treated dumortierite were prepared by the ordinary method, and a vibrational spectrum of $\mathrm{OH}$ near $3600 \mathrm{~cm}^{-1}$ was measured by an IR spectroscopy.

Fig. 2 shows a result of the measurements. A weak absorption peak is present at $3500 \mathrm{~cm}^{-1}$. The peak width is about $25 \mathrm{~cm}^{-1}$. This is an evidence of $\mathrm{OH}$ in dumortierite crystal. Same peak is present in two natural dumortierite examined. The peak is present after heat treatment at $860^{\circ}$ $\mathrm{C}$ in air.

\section{EXPERIMENTAL Results}

Results of experimental runs are shown in Fig. 3. Representative runs are listed in Table 2 together with experimental con-

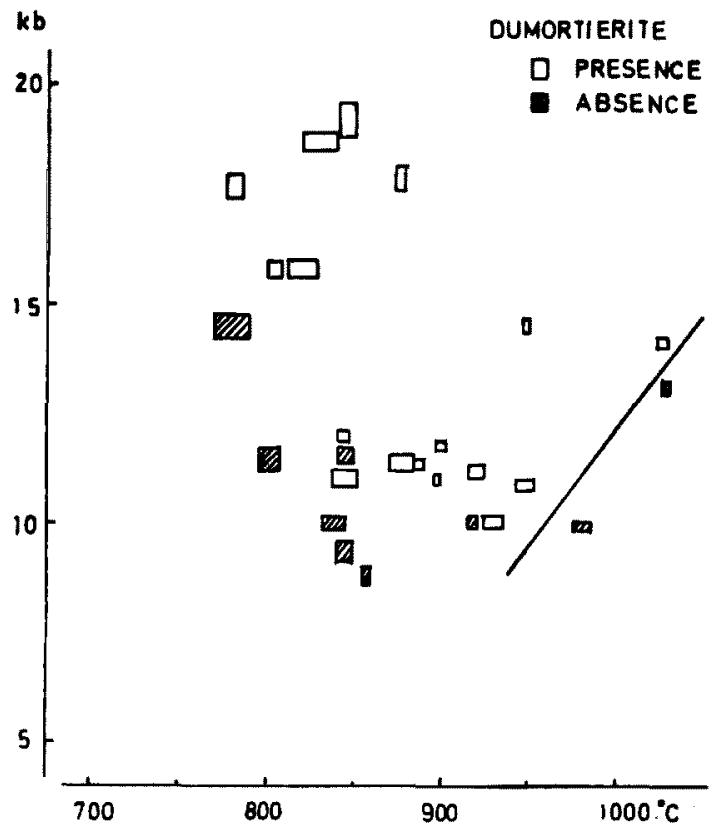

Fig. 3 P-T range of synthesis of dumortierite Dumortierite-out line is shown in the figure.

ditions. Vapor phase is present in all experimental runs, therefore vapor blew out from platinum tube when $\mathrm{Pt}$-capsules were

Table 2 Results of representative experimental runs

Chemistries of the starting materials " $a$ " and " $d$ " are given in Table 1. All experiments used by starting material " $a$ " are listed in this Table.

\begin{tabular}{c|cccc|c} 
sample & $\begin{array}{c}\text { temp } \\
{ }^{\circ} \mathrm{C}\end{array}$ & $\begin{array}{c}\text { press } \\
\mathrm{kb}\end{array}$ & $\begin{array}{c}\text { time } \\
\text { hours material }\end{array}$ & \multicolumn{1}{c}{ products } \\
\hline 3 & 870 & 11.6 & 46 & $\mathrm{a}$ & $\mathrm{d}+\mathrm{qtz}+\mathrm{cor}+\mathrm{b}+\mathrm{v}$ \\
25 & 780 & 14.5 & 32 & $\mathrm{a}$ & $\mathrm{qtz}+\mathrm{cor}+\mathrm{b}+\mathrm{v}$ \\
27 & 840 & 11.6 & 74 & $\mathrm{a}$ & $\mathrm{qtz}+\mathrm{cor}+\mathrm{b}+\mathrm{v}$ \\
34 & 830 & 18.8 & 49 & $\mathrm{a}$ & $\mathrm{d}+\mathrm{qtz}+\mathrm{cor}+\mathrm{b}+\mathrm{v}$ \\
43 & 805 & 17.7 & 1 & $\mathrm{~d}$ & $\mathrm{~d}+\mathrm{cor}+\mathrm{b}+\mathrm{v}$ \\
31 & 840 & 9.4 & 95 & $\mathrm{~d}$ & $\mathrm{cor}+\mathrm{qtz}+\mathrm{b}+\mathrm{v}$ \\
15 & 840 & 12 & 48 & $\mathrm{~d}+\mathrm{SiO} 2$ & $\mathrm{~d}+\mathrm{qtz}+\mathrm{v}$ \\
56 & 950 & 11 & 7 & $\mathrm{~d}$ & $\mathrm{~d}+\mathrm{cor}+\mathrm{glass}+\mathrm{v}$ \\
57 & 980 & 9.9 & 7 & $\mathrm{~d}$ & $\mathrm{cor}+\mathrm{qtz}+\mathrm{glass}+\mathrm{v}$ \\
60 & 920 & 10 & 8 & $\mathrm{~d}$ & $\mathrm{cor}+\mathrm{qtz}+\mathrm{b}+\mathrm{v}$ \\
53 & 920 & 11.2 & 21 & $\mathrm{~d}$ & $\mathrm{~d}+\operatorname{cor}+\mathrm{glass}+\mathrm{v}$ \\
52 & 1030 & 13 & 5 & $\mathrm{~d}$ & cor $+\mathrm{s} 111+\mathrm{glass}+\mathrm{v}$ \\
48 & 900 & 11.6 & 7 & $\mathrm{~d}$ & $\mathrm{~d}+\operatorname{cor}+\mathrm{b}+\mathrm{v}$ \\
\hline
\end{tabular}

d: dumortierite, cor: corundum, qtz: quartz, sill; sillimanite, $\mathrm{b}$ : brown material, v: vapor 
cut out after experimental runs. Dumortierite could not be produced below $10 \mathrm{~kb}$, $870^{\circ} \mathrm{C}$. Corundum, quartz and brown material are present instead of dumortierite. Brown material is partly soluble in water, and tiny crystals of $\mathrm{H}_{3} \mathrm{BO}_{3}$ were formed after evaporation of water. Brown material may be rich in $\mathrm{B}_{2} \mathrm{O}_{3}$ component. Brown color is due to translucent nature of fine aggregate of crystals. Absence of dumortierite in low pressure experimental runs does not mean unstability of dumortierite in low pressure. Corundum, quartz and brown material may be a metastable mineral assemblage. Coexistence of corundum and quartz is surely metastable with respect to sillimanite.

Dumortierite synthesized below $870^{\circ} \mathrm{C}$ and above $10 \mathrm{~kb}$ coexist with small amount of corundum and brown material. Dumortierite coexisting with quartz were synthesized from the starting material added by considerable amount of $\mathrm{SiO}_{2}$. Above $900^{\circ} \mathrm{C}$ transparent glasses are present together with corundum and dumortierite. Amount of glass increase with increasing temperature. Dumortierite is absent in high temperature side of line shown in Fig. 3 where corundum, sillimanite and glass occur.

At high pressure, dumorierite was formed after one hour. The rapid reaction rate suggests that large dumortierite crystals of longer run durations synthesized at high pressure may be in equilibrium with other phases.

Dumortierite could not be produced from the starting material of " $\mathrm{a}$ " at $840^{\circ} \mathrm{C}$, $11.6 \mathrm{~kb}$. At higher temperature and pressure, dumortierite were synthesized together with considerable amount of corundum and quartz.

It is notewotrhy that metastable assem-
Table 3 Chemical compositions of synthetic dumortierite.

\begin{tabular}{l|ccccccc} 
sanple & 1 & 5 & 10 & 3 & 14 & 15 & 56 \\
\hline temp ${ }^{\circ} \mathrm{C}$ & 850 & 810 & 840 & 880 & 815 & 840 & 950 \\
press $\mathrm{kb}$ & 11 & 16 & 12 & 11.6 & 16 & 12 & 11 \\
\hline $\mathrm{SiO}_{2}$ & 28.28 & 28.15 & 28.32 & 28.63 & 28.59 & 28.61 & 27.96 \\
$\mathrm{Al}_{2} \mathrm{O}_{3}$ & 61.43 & 60.92 & 61.56 & 61.73 & 61.16 & 61.32 & 61.70 \\
$\mathrm{~B}_{2} \mathrm{O}_{3}$ & 9.73 & 10.33 & 9.57 & 9.14 & 9.73 & 9.56 & 9.73 \\
$\mathrm{H}_{2} \mathrm{O}^{\circ}$ & 0.56 & 0.59 & 0.55 & 0.49 & 0.51 & 0.50 & 0.61 \\
\hline Total & 100.00 & 99.99 & 100.00 & 99.99 & 99.99 & 99.99 & 100.00 \\
\hline $\mathrm{Si}$ & 2.648 & 2.629 & 2.654 & 2.688 & 2.677 & 2.681 & 2.618 \\
Al IV & 0.352 & 0.371 & 0.346 & 0.312 & 0.323 & 0.319 & 0.382 \\
\hline B & 1 & 1 & 1 & 1 & 1 & 1 & 1 \\
\hline Al & 0.428 & 0.334 & 0.452 & 0.518 & 0.427 & 0.454 & 0.427 \\
B VI & 0.572 & 0.666 & 0.548 & 0.428 & 0.573 & 0.546 & 0.573 \\
Al & 6 & 6 & 6 & 6 & 6 & 6 & 6 \\
\hline OH & 0.350 & 0.370 & 0.345 & 0.310 & 0.321 & 0.317 & 0.380
\end{tabular}

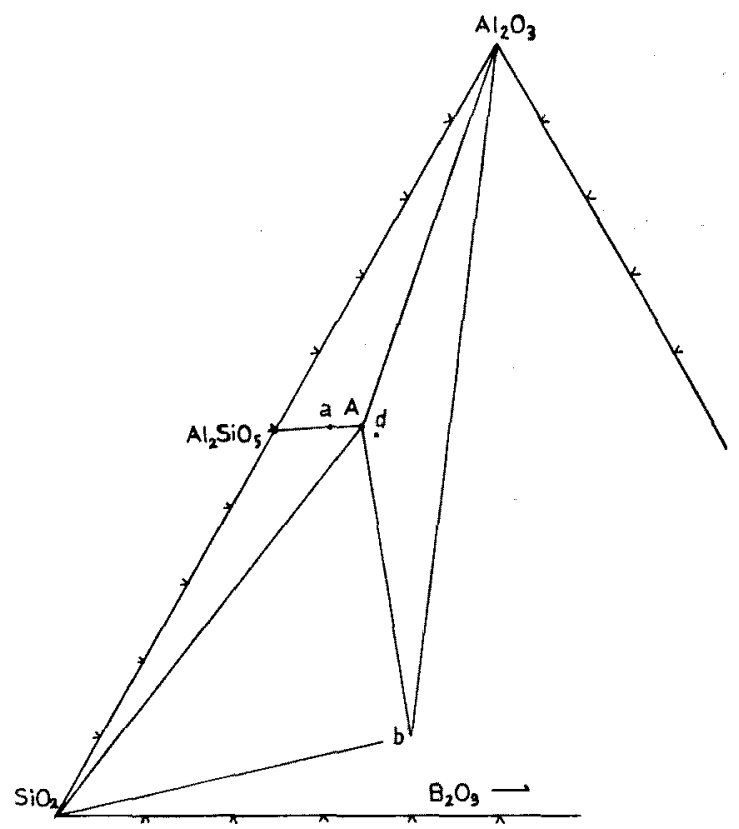

Fig. 4 Phase relations of the examined system at $850^{\circ} \mathrm{C}$

a, d: starting materials (see Table 1), A: synthetic dumortierite, b: brown material (finegrained undetermined material).

blage of corundum +quartz occurs at low pressure and/or low temperature region, and synthesis of dumortierite depends on bulk composition of starting materials.

Analytical results of dumortierite are given in Table 3 . Chemistry of dumorierite is similar with each other regardless of wide 
range of synthetic temperature and difference of coexisting minerals. Fig. 4 shows relationships between chemical compositions of starting materials and products in subsolidus temperature region. Corundum, dumortierite and brown material are produced from the starting material " $d$ ". Brown material may be $\mathrm{SiO}_{2}$-rich and $\mathrm{Al}_{2} \mathrm{O}_{3}$-poor in chemical composition as shown in Fig. 4. Starting material " $a$ " is on a line connecting sillimanite and dumortierite.

\section{Natural Dumortierite}

Dumortierite occur commonly in the Ryoke pelitic gneisses. Chemical compositions of these dumortierite may be different from those of synthetic ones, because condition of formation is greatly different from each other. Examination of natural dumortierite revealed the following facts. 1) Infrared absorption peak of $\mathrm{OH}$ vibration is present. 2) $\mathrm{B}_{2} \mathrm{O}_{3}$ content of dum- ortierite is similar to that of synthetic one. 3) Appreciable amount of $\mathrm{Mg}$ replaces $\mathrm{Al}$. These data suggest substitutions of $\mathrm{Al}-\mathrm{O} \rightleftharpoons$ $\mathrm{Al}-\mathrm{OH}$ and $\mathrm{AlO}_{6} \rightleftharpoons \mathrm{BO}_{6}$.

$\mathrm{X}$-ray structural analysis based on $\mathrm{Al}_{7}$ $\mathrm{O}_{3}\left(\mathrm{BO}_{3}\right)\left(\mathrm{SiO}_{4}\right)_{3}$ composition indicates that temperature factors of $\mathrm{Al}(1), \mathrm{O}(1)$ and $\mathrm{O}(2)$ are very large (Okamura and Ono, 1978). This supports presence of the substitutions described above.

\section{REFERENCES}

Claringbull, G.F. and Hey, M.H. (1958), New data for dumortierite. Min. Mag., 31, 901-907.

Okamura, F.P. and Ono, A. (1978), Crystal chemical peculiarity of dumortierite from Takato. Annual Meeting Abs. Mineral. Soc. Japan. 145 (in Japanese).

Ono, A. (1977), Petrological study of the Ryoke metamorphic rocks in the Takato-Shiojiri area, central Japan. J. Japan Assoc. Min. Petrol. Econ. Geol. 72, 453-468 (in Japanese).

Wyckoff, R.W.G. (1968), Crystal Structures, second edition vol. 4, Interscience Publishers.

\section{$\mathrm{Al}_{2} \mathrm{O}_{3}-\mathrm{SiO}_{2}-\mathrm{B}_{2} \mathrm{O}_{3}-\mathrm{H}_{2} \mathrm{O}$ 系におけるデュモティエライトの合成}

$$
\text { 小野晃 }
$$

デュモティエライトの高圧合成と分析結果によると，從来考えられてきた理想化学式のものは合成できなかっ た。広い温度範囲に渡って，また共存する鉱物（石英やコランダム）の種類に関倸なく，合成結晶の固溶範囲は 小さい。分析值は $\mathrm{B}_{2} \mathrm{O}_{3}$ が 9\%を超え，てれは $\mathrm{Al}$ のサイトに B が置換しているととを示す。また $\mathrm{SiO}_{4} \rightleftharpoons \mathrm{AlO}_{4}$ の置換もみとめられる。赤外吸収スペクトルによると，3500 $\mathrm{cm}^{-1} に \mathrm{OH}$ の振動による吸収ピークが認められた。 てれは Si と6配位の Al 結びつけている酸素が $\mathrm{OH}$ 亿置換されているととを示す。天然のデュモティエライ トにおいても同様の事柄が認められた。 